\title{
Growth and kinetics of lipids and fatty acids of the clam Venerupis pullastra during larval development and postlarvae
}

\author{
M.J. FERNÁNDEZ-REIRIZ ${ }^{1}$, A. PÉREZ-CAMACHO ${ }^{2}$, L.G. PETEIRO ${ }^{1}$ \& U. LABARTA ${ }^{1}$ \\ ${ }^{1}$ Consejo Superior Investigaciones Cientificas, Instituto de Investigaciones Marinas, Eduardo Cabello, Vigo, Spain; ${ }^{2}$ Centro \\ Oceanográfico de La Coruña, IEO, Muelle de Animas, La Coruña, Spain
}

\begin{abstract}
This study examines the larval development, metamorphosis and postlarval stage of Venerupis pullastra in relation to growth, lipids content and fatty acid composition, specifically those believed to be essential for most bivalves (i.e. 20:5n-3 and 22:6n-3). Clam larvae were fed with two species of microalgae supplied individually or mixed -Isochrysis galbana and Tetraselmis suecica-species normally used in bivalve hatcheries. Larvae fed with $T$. suecica showed a progressive accumulation of lipids and fatty acids but did not survive to metamorphosis. Contrarily, larvae fed with I. galbana or mixed diet showed a progressive decline in lipids and essential fatty acids (20:5n-3 and 22:6n-3) from the 1 pediveliger stage onwards, and a survival rate of $95 \%$ until the start of metamorphosis. The lower content in n-6 and the absence of 22:6n-3 in T. suecica diet might contribute to the massive mortality observed for larvae fed with this diet. That diet seems to fail in the supply of some particular nutrient that allows energetic transformation of reserves for growth and metamorphosis. Nevertheless, larvae fed on mixture diet showed higher weight growth values at postlarval stage than those larvae fed on I. galbana diet.
\end{abstract}

KEY wORDS: clam, fatty acids, growth, larval development, lipid's kinetic, microalgal diets, Venerupis pullastra

Received 16 March 2009, accepted 15 June 2009

Correspondence: M.J. Fernández-Reiriz, Consejo Superior de Investigaciones Cientificas, Instituto de Investigaciones Marinas, Eduardo Cabello, 6. 36208 Vigo,Spain.E-mail:mjreiriz@iim.csic.es

\section{Introduction}

Larval development and survival is determined by the energy reserves stored during two stages of development. One corresponds to embryonic development and is mainly governed by the endogenous reserves supplied to the eggs from the parents (Bayne 1973). The next stage is a previous period until metamorphosis when stored energy reserves are essential, and depends on the feed value of the diets supplemented for larval growth (Whyte et al. 1989, 1990).

Recently, an in-depth revision of lipid metabolism, Sewell (2005), has discussed the importance of the lipid matrix during bivalve larval development. Utting (1986) and Whyte et al. (1989, 1990), on the other hand, noted the importance of the protein content of the diet for strong larval growth up to metamorphosis, as well as the requirement of a diet sufficiently balanced in proteins, lipids and carbohydrates. Labarta et al. (1999) evaluated the growth and processes of energy acquisition in Ostrea edulis during larval development, as well as the role of lipids, proteins and carbohydrates from an energetic and structural perspective, and showed that lipids were the main source of metabolic energy for $O$. edulis throughout larval development.

The importance of lipids as a dietary requirement has been extensively studied for many species of bivalves over recent decades (Albentosa et al. 1994, 1996; Caers et al. 1998; Fernández-Reiríz et al. 1999; Soudant et al. 1999; Pernet et al. 2006). The fatty acid composition has been described for some bivalve species (Watanabe \& Ackman 1974; Holland 1978; Waldock \& Holland 1984; Hendriks et al. 2003; Milke et al. 2004). Nonetheless knowledge of fatty acid composition in $V$. pullastra during larval and postlarval development is lacking.

Existing results showed that long-chain (n-3) and (n-6) PUFA were important for mollusc larvae (Delaunay et al. 1993; Leonardos \& Lucas 2000), similar to many marine species. These criteria, as well as acceptability and digestibility, may help explain their nutritional value (Albentosa et al. 1994, 1996; Fernández-Reiríz et al. 1999).

Waldock \& Holland (1984) investigated the metabolism of fatty acids in Crassostrea gigas juveniles. This author pointed out that $C$. gigas has some capacity for elongating and

(c) 2009 The Authors

Journal compilation @ 2009 Blackwell Publishing Ltd 
desaturating n-3 fatty acids to produce n-3HUFA, although too low to sustain optimum growth. The same results were obtained by Chu \& Greaves (1991) for Crassostrea virginica where ${ }^{14}$ C-labelled 20:5n-3 and 22:6n-3 were not detected from labelled 18:3n-3. These findings are comparable to those observed by Albentosa et al. $(1994,1996)$ in $V$. pullastra spat and Ruditapes decussatus spat.

The requirement for certain fatty acids appears to be species dependent. Tapes semidecussatus and Mercenaria mercenaria require 22:6n-3, while Crassostrea sp. shows a fundamental requirement for 20:5n-3 (Helm \& Laing 1987). Both 20:5n-3 and/or 22:6n-3 can meet the bivalve requirements for n-3 PUFA (Fernández-Reiríz et al. 1999). Nonetheless, Pernet et al. (2007) reported that the mussel seemed better able that the oyster to selectively incorporate 20:5n-3 fatty acid.

The NMID fatty acids are preferably found in the polar lipids of mollusks (Ackman \& Hooper 1973; Irazu et al. 1984; Kraffe et al. 2004). Pathways for the biosynthesis of 20:2NMI and 22:2NMI fatty acids have been reported in the bivalve mollusks Scapharca broughtoni and Mytilus edulis (Zhukova 1991). These results indicated that mollusks have active fatty acid elongation and desaturation systems that allow synthesis of these NMI fatty acids. The NMIDs, specifically 20:2NMID, were observed in similar amounts to some PUFAs in the larval development stage of $O$. edulis, but became relatively less important from the onset of metamorphosis. Furthermore, these acids were only present in residual quantities during the postlarval stage (Labarta et al. 1999).

This study investigates the larval development, metamorphosis and postlarval stage of $V$. pullastra in relation to growth, kinetic response of lipids and the fatty acid composition, with regard to three experimental diets.

\section{Materials and methods}

\section{Larval cultivation}

Venerupis pullastra (L.) larvae were obtained from broodstock conditioned at the Instituto Español de Oceanografía (A Coruña, NW Spain). Spawning and larval culture were carried out following Pérez-Camacho et al. (1977). Larvae were maintained for 34 days until attaining the postlarval stage.

After 2 days of incubation of the eggs in $100 \mathrm{~L}$ glass fibre containers, D-veliger larvae stage was attained, showing a mean length of $98.6 \mu \mathrm{m}$. These larvae were transferred to $400 \mathrm{~L}$ tanks maintained at $18^{\circ} \mathrm{C}$ with filtered water $(1 \mu \mathrm{m})$ and 50 cells $\mu \mathrm{L}^{-1}$ of $I$. galbana clon T-ISO as diet concentration. The water and food was renewed every 2 days. After 11 days under these conditions, the larvae reached a mean length of $176.8 \mu \mathrm{m}$ (umbonate larvae), which allowed them to capture cells with the size of Tetraselmis suecica (about $7.64 \mu \mathrm{m}$ ). At this point, the experiment with different diets was initiated.

Two tanks for each experimental diet were deployed. The experiment was carried out within $100 \mathrm{~L}$ fibre glass tanks with filtered sea water $(1 \mu \mathrm{m})$ at $18{ }^{\circ} \mathrm{C}$ with a larval density of five larvae $\mathrm{mL}^{-1}$. The larvae were fed with two species of microalgae (I. galbana and T. suecica) supplied individually (100 cells $\mu \mathrm{L}^{-1}$ for $I$. galbana and its equivalent volume, 10 cells $\mu \mathrm{L}^{-1}$ for T. suecica) or mixed (50 cells $\mu \mathrm{L}^{-1}$ I. galbana and five cells $\mu \mathrm{L}^{-1}$ for $T$. suecica). The water and food were renewed every 2 days.

Larval samples for biochemical analysis were taken at day 2 (D larva), day 13 (umbonate larvae) day 17 (pediveliger larvae), day 22 (start of metamorphosis) and day 34 (postlarvae).

Size was determined using a binocular microscope with ocular micrometer (model SMZ-10, Nikon Instruments Europe, Amstelveen, The Netherlands). Individual dry weights (DW) were measured on glass microfibre filters (Cat № 1825-025, Whatman International Ltd, Maidstone, UK) after washing the larvae with distilled water and dried in an oven at $110^{\circ} \mathrm{C}$ for $3 \mathrm{~h}$. Organic weight (OW) was determined by the difference between the dry and ashed weight following combustion $\left(450{ }^{\circ} \mathrm{C}\right.$ for $4 \mathrm{~h}$ ). The weight was measured using an electronic microbalance (model M3P; Sartorius AG, Goettingen, Germany).

\section{Analysis of lipids and fatty acids}

Lipids were first extracted with chloroform:methanol (1:2; VWR International S.A.S., Briare, France) and, after centrifugation $(3246 \mathrm{~g})$, the precipitate was re-extracted with chloroform:methanol (2:1). Both supernatants were subsequently washed with chloroform:methanol:water (8:4:3) as described previously (Fernández-Reiríz et al. 1989). The solvents contained $0.05 \%$ butylated hydroxytoluene (Merck Schuchardt OHG, Hochenbrunn, Germany). To quantify total lipids, the method described by Marsh \& Weinstein (1966) was used with a tripalmitine standard (Sigma Aldrich Inc., Buchs, Switzerland). Samples were stored under nitrogen at $-70{ }^{\circ} \mathrm{C}$ until further processing. The results of lipids were transformed into their energy equivalent $\left(\mathrm{kJ}\right.$ ind ${ }^{-1} 10^{-6}$ ) following Beukema \& De Bruin (1979).

Fatty acids from total lipids were trans-esterified to methyl esters with methanolic hydrogen chloride (VWR 
International S.A.S., Briare, France) following Christie (1982). The acids were subsequently analysed on a gas 2 chromatograph (model 8500; Perkin-Elmer Inc., ${ }_{\mathrm{N}}^{\mathrm{MA}}$, USA) equipped with a fused silica capillary column (30-m length, 0.25 mm i.d.; model SP-2330, Supelco, PA, USA) and a PTV cold injector (Perkin-Elmer Inc.) operated in the solvent elimination mode. The injector temperature was $275^{\circ} \mathrm{C}$ and the column temperature was increased from 140 to $210^{\circ} \mathrm{C}$ at a rate of $1.0{ }^{\circ} \mathrm{C} \mathrm{min}^{-1}$, with $\mathrm{N}_{2}$ carrier gas $(0.069 \mathrm{~Pa}=10$ psi). Non-adecanoic acid (Sigma-Aldrich Inc., Buchs, Switzerland) was used as an internal standard and a response factor was calculated for each fatty acid for quantitative analyses. A combination of analytical procedures (GC-MS; gas chromatograph model HP5890 and mass detector model 35971, Agilent Technologies Inc., ${ }_{A}$ CA, USA) was required for conclusive structure determination of non-methylene-interrupted dienoic (NMID) fatty acids.

\section{Statistical analysis}

Homogeneity of variance was tested with the Bartlett test. When non-homogeneity, data were modified using logarithmic transformation. The differences between means of growth and lipid content over time were analysed using ANOva and a Tukey test at a significance level of $P<0.05$ (Snedecor \& Cochran 1980; Zar 1984). Correlations between clam growth and fatty acid contents were examined by Pearson's correlation coefficients.

\section{Results}

\section{Growth and survival}

The survival rate of larvae fed with I. galbana and the mixture of I. galbana and T. suecica was $95 \%$ until the start of metamorphosis (day 22). The larvae fed exclusively with T. suecica had a mortality rate above $40 \%$ at day 22 , which increased to $100 \%$ over the following two days, at which point the culture was ended.

The D larvae displayed significantly lower lengths and dry weights $(98.6 \pm 3.92 \mu \mathrm{m}$ and $0.12 \pm 0.04 \mu \mathrm{g})$ than the umbonate larvae $(176.8 \pm 5.92 \mu \mathrm{m}$ and $0.53 \pm 0.10 \mu \mathrm{g}$; ANOvA, $P<0.001)$. Significant changes were also observed in organic $(0.03 \pm 0.00$ and $0.19 \pm 0.00 \mu \mathrm{g}$ OW for $\mathrm{D}$ and umbonate larvae respectively; ANOva, $P<0.001)$ and lipidic content $\left(0.05 \pm 0.02\right.$ and $0.08 \pm 0.03 \mu \mathrm{g} \mu \mathrm{g} \mathrm{DW}^{-1}$ for $\mathrm{D}$ and umbonate larvae, respectively; ANOvA, $P<0.001)$.

Differences in growth parameters were observed between diets in some stages (Table 1; ANova, $P<0.05$ ). Larvae fed

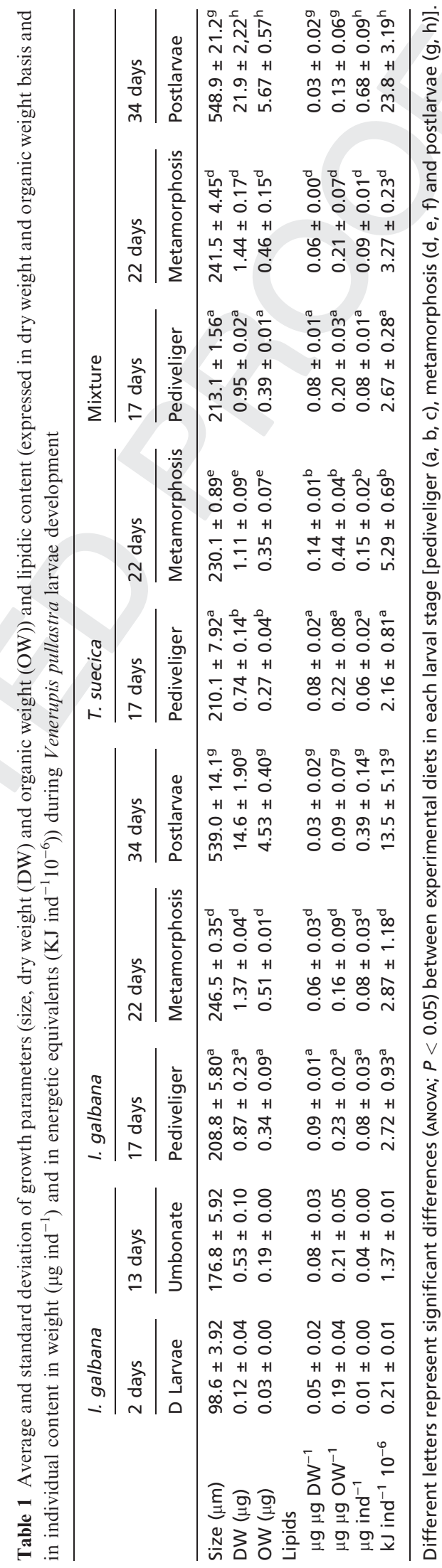


on $T$. suecica showed significant lower weight values than the other diets at day 17 whereas no differences in length were observed between diets (Table 1 ;-AnOva $P<0.05$ ). At the onset of metamorphosis (day 22), larvae fed with $T$. suecica showed significantly lower shell length and dry weight $(230.1 \pm 0.89 \mu \mathrm{m}$ and $1.11 \pm 0.09 \mu \mathrm{g}$; ANOVA $P<0.05)$ than larvae fed with I. galbana $(246.55 \pm 0.35 \mu \mathrm{m}$ and a weight of $1.37 \pm 0.04 \mu \mathrm{g}$ ) or the mixture diet $241.5 \pm$ $4.45 \mu \mathrm{m}$ and $1.44 \pm 0.17 \mu \mathrm{g}$ ). After metamorphosis, the postlarvae fed with $I$. galbana presented similar lengths than those fed on mixture diet $(539.0 \pm 14.1$ and $548.9 \pm$ $81.2 \mu \mathrm{m}$, respectively) but lower weight values (14.6 \pm 1.90 and $21.9 \pm 2.22 \mu \mathrm{g}$ for I. galbana and mixture diets, respectively; ANOvA $P<0.05$ ).

The highest increase in growth rates (length or weight) were observed between metamorphosis and postlarval stage (Fig. 1). Nonetheless, no significant differences were detected in length or weight growth rates between diets in any of the larval stages (Fig. 1).

The lipid content of larvae fed with $T$. suecica increased over the 22 day experimental period (onset of the metamorphosis). However, with the other diets the lipid content showed the maxima values at the pediveliger stage and a decrease onwards, showing the lowest content in the postlarval stage (day 34; ANOVA $P<0.05$ ). In the pediveliger stage, the energy content of the lipids was similar (ANOvA; $P>0.05$ ) in the larvae fed with the three diets $\left(\sim 2.5 \mathrm{~kJ}\right.$ ind $^{-1} 10^{-6}$, Table 1$)$. At the onset of metamorphosis, the larvae fed with $T$. suecica showed significantly higher lipid content $\left(5.3 \mathrm{~kJ}\right.$ ind ${ }^{-1} 10^{-6}$, ANOvA, $P<0.05)$ although they did not survive metamorphosis. The largest lipid content (ANOVA, $P<0.001$ ) in the postlarval stage was found in the larvae fed with the mixed diet $\left(23.8 \mathrm{~kJ}\right.$ ind $^{-1}$ $10^{-6}$ ) due to their higher weight values (Table 1).

Equations were derived to describe the evolution of lipid content, dry and organic weight in their energetic equivalents ( $\mathrm{kJ} \mathrm{g}^{-1}$, dry weight, basis, Fig. 2) from the onset of the dietary experience. Larvae fed with $T$. suecica showed a linear or exponential increase along the development in lipid content and weight values (Fig. 2; Appendix 1) whereas larvae fed with I. galbana or the mixed diet showed a maximum in the pediveliger stage and a progressive decline in lipid content and weight (Fig. 2; Appendix 1).

\section{Fatty acids}

\section{Fatty acid composition of the diets}

Table 2 shows the composition of fatty acids of the three different experimental diets.
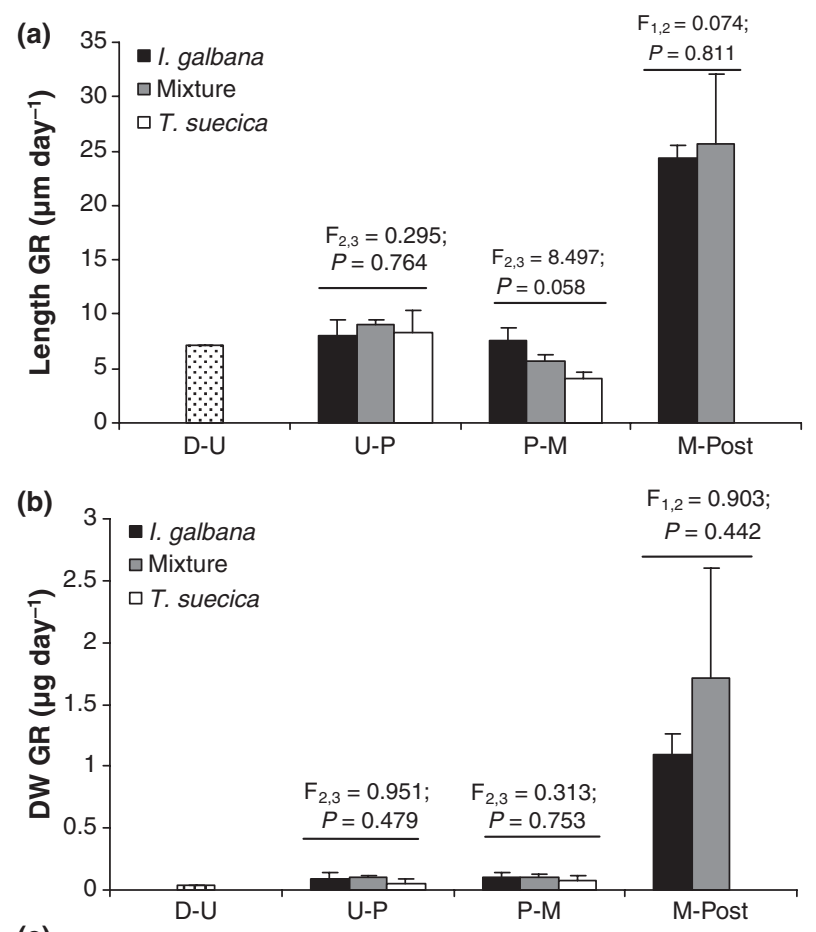

(c)

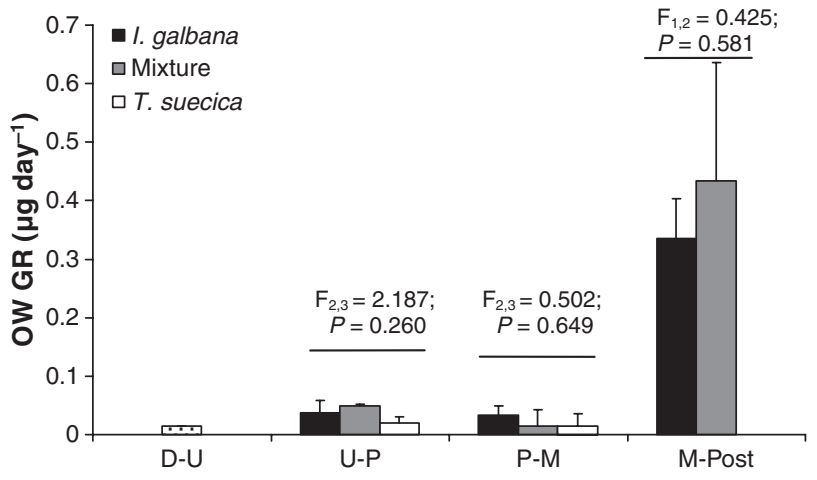

Figure 1 Length growth rate $\left(\mu \mathrm{m} \mathrm{day}^{-1}\right)(\mathrm{a})$, dry weight growth rate $\left(\mu \mathrm{g} \mathrm{day}^{-1}\right)(\mathrm{b})$ and organic growth rate $\left(\mu \mathrm{g} \mathrm{day}^{-1}\right)(\mathrm{c})$ over Venerupis pullastra larval development (D-U: growth rate from veliger $\mathrm{D}$ to umbonate veliger; U-P: growth rate from umbonate veliger to pediveliger; $\mathrm{P}-\mathrm{M}$ : growth rate from pediveliger to metamorphosis, M-Post: growth rate from metamorphosis to postarvae) with ANOvA results for differences between diets.

The main fatty acids found in I. galbana diet were 14:0, 16:0, 18:0, 18:1n-9, 18:4n-3 and 22:6n-3. The total fatty acid content was $148.9 \mu \mathrm{g}$ mg DW-1 (64.8, 34.5 and $49.6 \mu \mathrm{g} \mathrm{mg}_{\perp} \mathrm{DW}-1$ for saturated, monoenoic and polyenoic fatty acids, respectively). The content of n-6 fatty acids was $11.3 \mu \mathrm{g} \mathrm{mg}$ DW-1 and $38.1 \mu \mathrm{g} \mathrm{mg}$ DW-1 for $\mathrm{n}-3$ PUFA. The n-3:n-6 and n-6:n-3 ratios were 3.4 and 0.3 , respectively.

In $T$. suecica diet the main fatty acids recorded were 16:0, 18:0, 18:1n-9, 18:3n-3, and 20:5n-3. The total fatty acids 

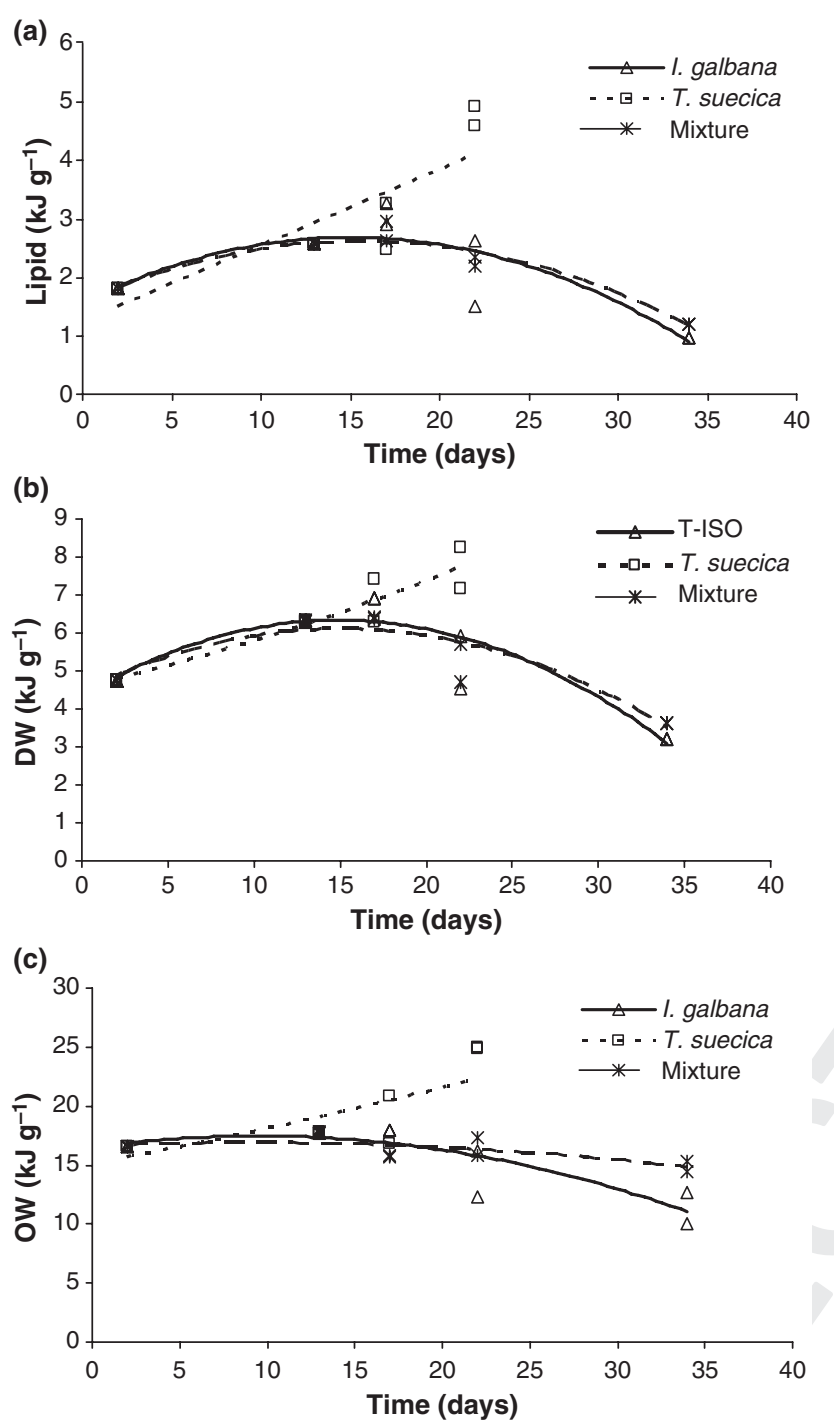

Figure 2 Fits on the evolution of lipid content (a) dry (b) and organic weight (c) (expressed in energy equivalents $\left(\mathrm{kJ} \mathrm{g}^{-1}\right)$ during larval development of Venerupis pullastra fed with different diets.

content was three times lower than in the other experimental diets, $45.1 \mu \mathrm{g} \mathrm{mg}$ DW-1 (18.2, 15.5 and $11.4 \mu \mathrm{g}$ mg DW-1 for saturated, monoenoic and polyenoic fatty acids, respectively). n-6 fatty acid content was $1.88 \mu \mathrm{g}$ mg DW-1 and for n-3 PUFA was $9.5 \mu \mathrm{g} \mathrm{mg} \mathrm{DW}^{-1}$. The n-3:n-6 ratio was 5.1, and 0.2 for $n-6: n-3$.

The main fatty acids found in the diet composed of I. galbana + T. suecica were 16:0, 18:0, 18:1n-9, 18:4n-3, $18: 3 n-3,14: 0,20: 5 n-3$ and 22:6n-3. The main groups were saturated fatty acids $\left(60.2 \mu \mathrm{g} \mathrm{mg} \mathrm{DW} \mathrm{DW}^{-1}\right)$, polyunsaturated fatty acids $\left(54.6 \mu \mathrm{g} \mathrm{mg} \mathrm{DW} \mathrm{DW}^{-1}\right)$ and monounsaturated fatty acids $\left(28.6 \mu \mathrm{g} \mathrm{mg} \mathrm{DW}^{-1}\right)$. The n-3PUFAs content was
$9.5 \mu \mathrm{g} \mathrm{mg} \mathrm{DW}^{-1}$. The n-3:n-6 ratio was 2.9 , and 0.5 for n-6:n-3.

\section{Fatty acid composition of the clam}

Table 3 shows the main fatty acids content and groups of fatty acids ( $\mu \mathrm{g} \mathrm{mg} \mathrm{DW}^{-1}$ ) along the larval development with different experimental diets.

From a developmental point of view, we observed for some fatty acids (16:0 and 18:0) a progressive increase until metamorphosis with a sharp decline in postlarvae stage for the three experimental diets. In the case of $18: 4 n-3$, 20:2NMID and 22:6n-3, we observed an opposite trend, with a progressive decrease for the three experimental diets until postlarvae stage, but with significant lower values in larvae fed with $T$. suecica (Table 3; ANOvA, $P<0.05$ ). Another group of fatty acids (18:1n-9, 18:2n-6, 18:3n-3, 20:5n-3 and 22:4n-6) showed the latter trend for I. galbana and mixture diets but a continuous accumulation in larvae fed on $T$. suecica (Table 3; ANOvA, $P<0.05$ ). With regard to 20:4n-6, although we observed the later trend, changes in content during development were not significant for any experimental diet.

From a diet point of view, the 20:4n-6 content at pediveliger stage was significantly higher in larvae fed on $T$. suecica. Similarly the 20:5n-3 was significantly higher in larvae fed on $T$. suecica, whereas the 22:6n-3 was higher in the larvae fed with I. galbana and mixed diets in all the developmental stages (Table 3; ANOvA, $P<0.05$ ).

The larvae fed with $T$. suecica showed a progressive increase on the total fatty acids content over development $(P<0.05)$, reaching significantly greater quantities at metamorphosis (Table 3; ANOva, $P<0.05$ ). In the other two diets the total fatty acid content decreased significantly during the development $(P<0.05)$, reaching postlarval stage with the lowest content. The behavior described above was also observed for the saturated, monoenoic and polyenoic fatty acids (Table 3 ).

\section{Relationship between growth and fatty acids}

No significant correlation was observed between weight growth values and dietary fatty acids (data not shown).

Correlation analysis between fatty acids content in larvae and weight growth during larval and postlarval development of $V$. pullastra revealed various positive and negative correlations with fatty acids or with their ratios (Table 4).

In the first larval stages (D and umbonates larvae; larvae fed with I. galbana) larval weight was positively related to

(C) 2009 The Authors

Journal compilation ๔ 2009 Blackwell Publishing Ltd Aquaculture Nutrition 
some fatty acids (among others 22:6n-3, n3:n6 ratio and total fatty acids content; Table 4A) and negatively related to 18:0, 20:5n-3, 20:2NMID, $\Sigma$ Saturated and $\Sigma$ n-11. In the successive developmental stages (from pediveliger to postlarvae) all the significant correlations indicated a negative relationship between weight growth of larvae fed with I. galbana and the content of main fatty acids (including 20:5n-3, 20:2NMID and 22:6n-3; Table 4B). Nonetheless, growth of larvae fed with $T$. suecica, showed positive relationships with six fatty acids and only one negative correlation with 18:4n-3 content (Table 4C). With the mixture diet, weight growth were significantly and negatively related to five fatty acids, none of which were the essential fatty acids $20: 5 n-3$ or 22:6n-3, whereas a significant relationship was observed with the 20:2NMID content (Table 4D).

Table 2 Fatty acid composition of experimental diets

\begin{tabular}{|c|c|c|c|}
\hline & I. galbana & T. suecica & Mixture \\
\hline & $\mu \mathrm{g} \mathrm{mg} \mathrm{DW} W^{-1}$ & $\mu \mathrm{g} \mathrm{mg} \mathrm{DW}^{-1}$ & $\mu \mathrm{g} \mathrm{mg} \mathrm{DW}^{-1}$ \\
\hline $14: 0$ & $21.3 \pm 0.00$ & $0.81 \pm 0.02$ & $8.10 \pm 0.31$ \\
\hline $15: 0$ & $1.42 \pm 0.01$ & $0.30 \pm 0.00$ & $0.41 \pm 0.02$ \\
\hline $16: 0$ & $25.4 \pm 0.40$ & $12.3 \pm 0.11$ & $27.5 \pm 0.61$ \\
\hline $16: 1 n-9$ & $2.11 \pm 0.00$ & $0.80 \pm 0.01$ & $1.04 \pm 0.12$ \\
\hline $16: 1 n-7$ & $4.10 \pm 0.03$ & $0.90 \pm 0.03$ & $4.10 \pm 0.11$ \\
\hline $16: 4 n-3$ & $0.23 \pm 0.01$ & nd & nd \\
\hline $17: 0$ & $1.40 \pm 0.02$ & $0.71 \pm 0.02$ & $1.71 \pm 0.20$ \\
\hline $17: 1 n-7$ & $0.50 \pm 0.01$ & nd & nd \\
\hline 18:0 & $14.8 \pm 0.20$ & $3.73 \pm 0.11$ & $22.5 \pm 0.62$ \\
\hline $18: 1 n-9$ & $26.2 \pm 0.31$ & $12.1 \pm 0.20$ & $21.1 \pm 0.51$ \\
\hline $18: 1 n-7$ & $1.70 \pm 0.01$ & $1.04 \pm 0.01$ & $2.32 \pm 0.10$ \\
\hline $18: 2 n-6$ & $4.11 \pm 0.01$ & $1.72 \pm 0.12$ & $8.10 \pm 0.31$ \\
\hline $18: 3 n-6$ & $0.40 \pm 0.00$ & nd & $1.61 \pm 0.20$ \\
\hline $18: 3 n-3$ & $4.80 \pm 0.03$ & $6.10 \pm 0.31$ & $12.0 \pm 0.81$ \\
\hline $18: 4 n-3$ & $17.4 \pm 0.02$ & nd & $19.2 \pm 0.51$ \\
\hline $18: 5 n-3$ & $1.61 \pm 0.21$ & $0.41 \pm 0.00$ & nd \\
\hline $20: 0$ & $0.60 \pm 0.00$ & $0.13 \pm 0.01$ & nd \\
\hline $20: 1 n-9$ & nd & $0.72 \pm 0.02$ & nd \\
\hline $20: 3 n-6$ & $3.50 \pm 0.10$ & nd & $0.92 \pm 0.03$ \\
\hline $20: 4 n-6$ & $1.20 \pm 0,91$ & $0.22 \pm 0.10$ & $0.71 \pm 0.02$ \\
\hline $20: 4 n-3$ & $1.10 \pm 0.20$ & nd & nd \\
\hline $20: 5 n-3$ & $0.83 \pm 0.01$ & $2.90 \pm 0.03$ & $5.60 \pm 0.31$ \\
\hline $22: 5 n-6$ & $2.21 \pm 0,01$ & nd & $1.31 \pm 0.12$ \\
\hline $22: 5 n-3$ & $0.42 \pm 0.02$ & nd & nd \\
\hline $22: 6 n-3$ & $11.8 \pm 0.10$ & nd & $3.91 \pm 0.30$ \\
\hline$\Sigma$ Saturated & 64.8 & 18.2 & 60.2 \\
\hline$\Sigma$ Monoenoic & 34.5 & 15.5 & 28.6 \\
\hline$\Sigma$ Polyenoic & 49.6 & 11.4 & 54.6 \\
\hline$\Sigma$ Total FA & 148.9 & 45.1 & 143.4 \\
\hline$\Sigma \mathrm{n}-3$ & 38.1 & 9.51 & 40.3 \\
\hline$\Sigma n-6$ & 11.3 & 1.92 & 13.9 \\
\hline$\Sigma \mathrm{n}-7$ & 6.20 & 1.89 & 6.40 \\
\hline$\Sigma n-9$ & 28.3 & 13.6 & 22.1 \\
\hline$\Sigma$ n-3 PUFA & 13.0 & 2.90 & 9.51 \\
\hline$n-3: n-6$ & 3.37 & 5.10 & 2.89 \\
\hline$n-6: n-3$ & 0.30 & 0.20 & 0.34 \\
\hline
\end{tabular}

\section{Discussion}

In general, bivalves fed with multi-specific microalgal diets show higher growth than those fed with mono-specific diets (Albentosa et al. 1993; Milke et al. 2004). In the present study, diets comprised of I. galbana and the mixture diets (I. galbana and T. suecica) showed higher growth values in length and weight during larval development of $V$. pullastra than those fed with $T$. suecica. Furthermore, only these diets led to survival past metamorphosis to the postlarval stage. Larvae fed with mixture diet showed higher growth values at postlarval stage than larvae fed on I. galbana diet.

Numerous studies have examined the nutritional value of microalgal species for bivalve mollusc culture (Webb \& Chu 1983; Ferreiro et al. 1990; Albentosa et al. 1993, 1996; Delaunay et al. 1993; Fernández-Reiríz et al. 1998, 2006; Pérez-Camacho et al. 1998; Milke et al. 2004). The size and cellular volume of $T$. suecica is greater than I. galbana (7.64 $\mu \mathrm{m}$ and $249.85 \mu^{3}$ compared to $4.0 \mu \mathrm{m}$ and $35.07 \mu^{3}$, respectively). However, both can be efficiently retained by bivalve filtration system (Albentosa et al. 1993, 1996). The digestibility of the microalgal cells may be another key factor for growth. Romberger \& Epifanio (1981) reported 10 times lower assimilation efficiency of $T$. suecica than I. galbana cells by $C$. virgínica.

In our study, significant relationships were observed between weight growth and fatty acid composition of larvae, but no correlation was observed between growth and dietary fatty acids. In agreement, Leonardos \& Lucas (2000) observed significant correlation between certain larval fatty acids (i.e. n-3 fatty acids) and growth in M. edulis larvae. However, the latter could not be extrapolated directly to similar relationships between dietary fatty acids and larval growth (Leonardos \& Lucas 2000).

Despite of the nutritional importance of the $n-3$ group that includes 20:5n-3 and 22:6n-3, Pearson's correlation only showed significant negative correlation with growth and n-3 group when larvae were cultivated with I. galbana. This diet was used from the beginning of the experimentation. However, feeding with the other two diets was initiated at the umbonate phase which can suggest that fatty acids are not only transferred but accumulated in the food web. Results also showed a negative correlation between growth and the 20:2NMID fatty acid content in larvae fed with I. galbana and mixed diet. Latter results suggest that this fatty acid have a significant role in determining the weight of the larvae $V$. pullastra despite of their low content. Although little is known about the function of the NMID fatty acids, the pathways for their biosynthesis in mollusc have been 


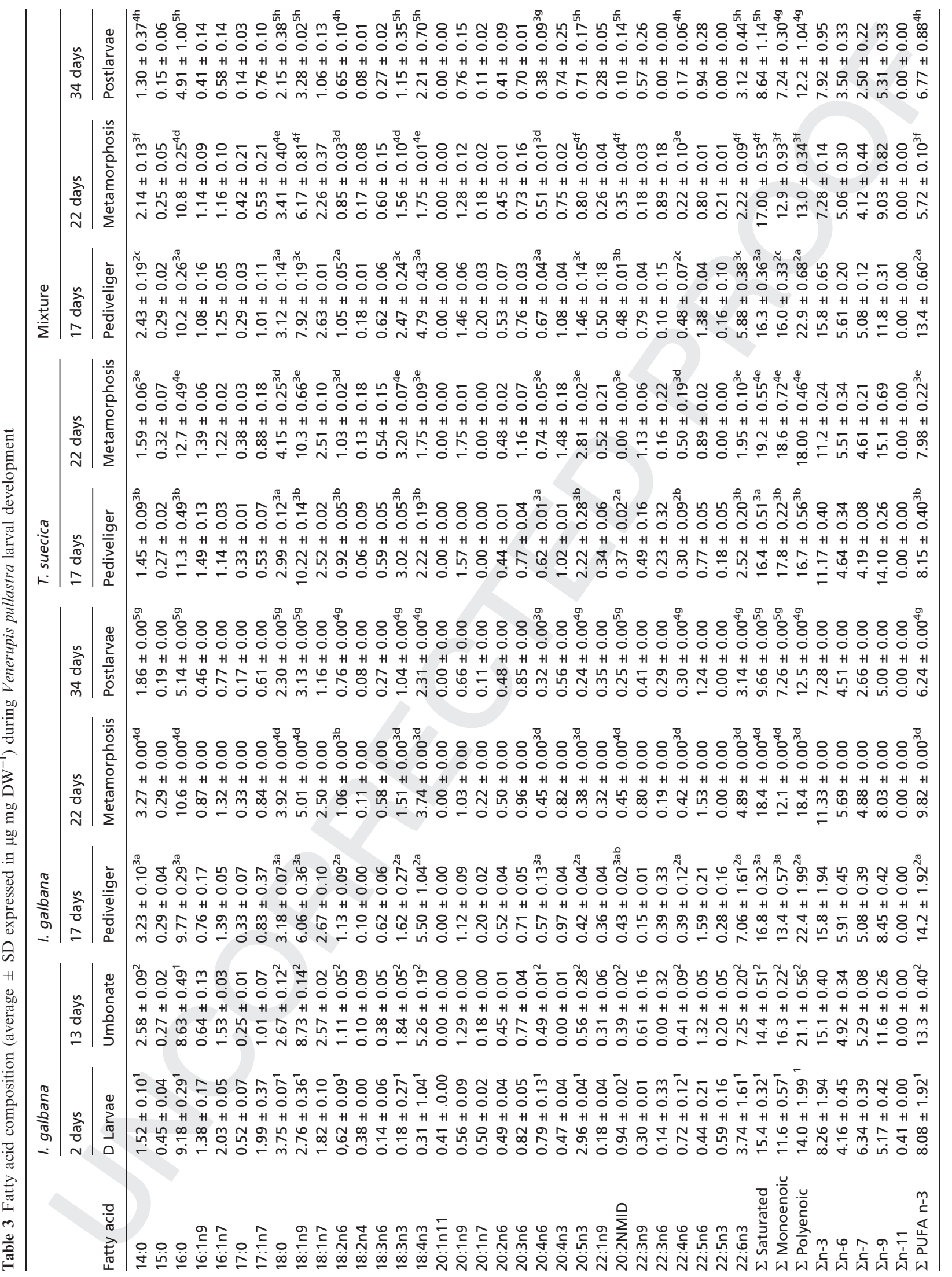

(c) 2009 The Authors

Journal compilation (c) 2009 Blackwell Publishing Ltd Aquaculture Nutrition 


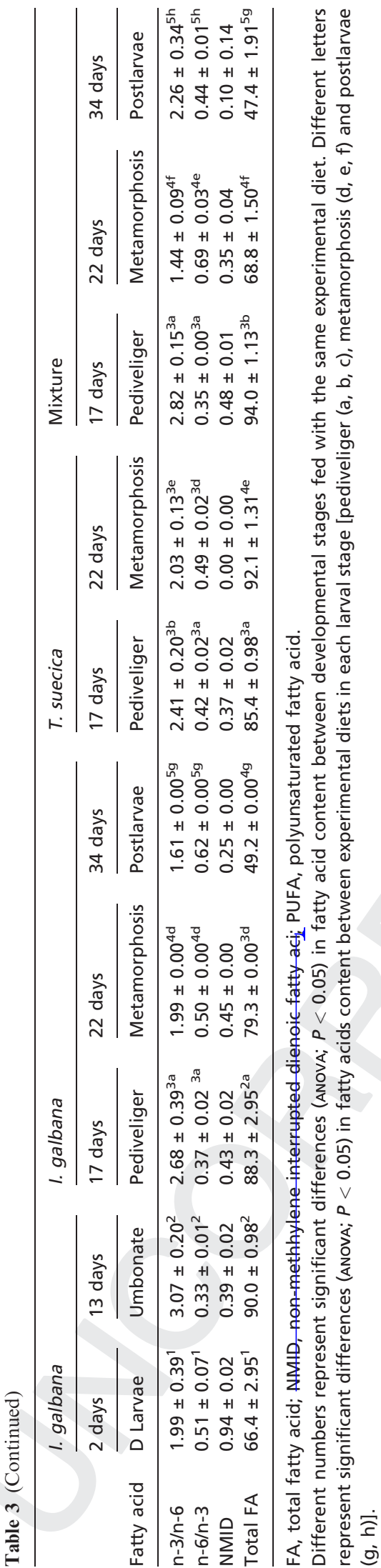

established (Zhukova 1991) and, since this group of fatty acids are not detected in the algal diets may have been entirely synthesized by the $V$. pullatra larvae.

Alkanani et al. (2007) working with adults of $M$. edulis showed that although n-3 were significantly correlated with growth, stepwise regression did not find n-3 in combination with other variables to be an important growth predictor. However, the stepwise regression showed that 20:2NMID fatty acid explained the major percentage of the variance of the mussel growth and consequently this fatty acid is considered as a major predictor for mussel growth. The survival during larval development may depend on the ability to develop new structures, including shells, while reserves are being consumed (Labarta et al. 1999; Veniot et al. 2003). The absence of 20:2NMID could be related to the failure of metamorphosis in larvae fed with $T$. suecica.

Larvae fed with $T$. suecica reached day 17 (pediveliger stage) with an intermediate size compared to the other two diets and dry weight values significantly lower than larvae fed with I. galbana and mixed diet. At day 22, majority of larvae are close to metamorphosis or it has been already initiated.

Table 4 Pearson's correlation coefficient between larval fatty acids and weight growth values ( $\mu \mathrm{g} \mathrm{DW}$ indiv $^{-1}$ ) for $V$. pullastra. (A) before the onset of the experimental diets and for larvae fed with Isochrysis, (B), Tetraselmis, (C) or Mixture (D) diets

\begin{tabular}{|c|c|c|c|c|}
\hline & $\begin{array}{l}\text { I. galbana } \\
\text { (A) }\end{array}$ & $\begin{array}{l}\text { I. galbana } \\
\text { (B) }\end{array}$ & $\begin{array}{l}\text { T. suecica } \\
\text { (C) }\end{array}$ & $\begin{array}{l}\text { Mixture } \\
\text { (D) }\end{array}$ \\
\hline Fatty acid & DW & DW & DW & DW \\
\hline $14: 0$ & $0.992 * *$ & $-0.991 * *$ & $0.997 * *$ & -0.886 * \\
\hline $16: 0$ & ns & $-0.978 * *$ & $0.964 *$ & $-0.903 *$ \\
\hline $18: 0$ & $-0.989 *$ & $-0.869 *$ & ns & $-0.883^{*}$ \\
\hline $18: 1 n-9$ & $0.994 * *$ & $-0.938 * *$ & $0.974 *$ & -0.850 * \\
\hline $18: 2 n-6$ & 0.984 * & $-0.982 * *$ & 0.951 * & ns \\
\hline $18: 3 n-3$ & $0.987 *$ & $-0.982 * *$ & 0.957 * & ns \\
\hline $18: 4 n-3$ & $0.995 * *$ & $-0.848 *$ & $-0.980 *$ & ns \\
\hline $20: 4 n-6$ & ns & ns & ns & ns \\
\hline $20: 5 n-3$ & $-0.999 * *$ & $-0.976 * *$ & ns & ns \\
\hline 20:2NMID & $-0.986 *$ & $-0.985 * *$ & ns & -0.864 * \\
\hline $22: 4 n-6$ & ns & $-0.955 * *$ & ns & ns \\
\hline $22: 6 n-3$ & $0.998 * *$ & $-0.849 *$ & ns & ns \\
\hline$\Sigma$ Saturated & $-0.998 * *$ & $-0.972 * *$ & ns & $-0.904 *$ \\
\hline$\Sigma$ Monoenoic & $1.000 * *$ & $-0.978 * *$ & ns & -0.860 * \\
\hline$\Sigma$ Polyenoic & $1.000 * *$ & $-0.923 * *$ & $0.959 *$ & ns \\
\hline$\Sigma n-3 P U F A$ & $1.000 * *$ & $-0.850 *$ & ns & ns \\
\hline$\sum n-3$ & $\mathrm{Ns}_{\lambda}$ & $-0.824^{*}$ & ns & ns \\
\hline$\sum n-6$ & $\mathrm{Ns} \hat{\lambda}_{\lambda}$ & $-0.914^{\star}$ & ns & ns \\
\hline$\sum n-7$ & $\mathrm{Ns}$ & $-0.974 * *$ & ns & ns \\
\hline$\sum n-9$ & $0.994 * *$ & $-0.979 * *$ & ns & ns \\
\hline$\sum n-11$ & $-1.000 * *$ & ns & ns & ns \\
\hline$\sum n-3 / \sum n-6$ & $1.000 * *$ & ns & ns & ns \\
\hline $\begin{array}{l}\text { Total } \\
\text { fatty acids }\end{array}$ & $0.998 * *$ & $-0.974 * *$ & ns & ns \\
\hline
\end{tabular}


At this point, larvae fed with $T$. suecica showed lower weight growth that those fed with I. galbana and mixed diet but higher lipid content (Table 1). Similarly, total fatty acids content showed higher values for larvae fed with $T$. suecica, although this diet showed the lowest content in total fatty acids. The latter could indicate that larvae fed with $T$. suecica were lacking of some particular nutrient that prevent an adequate utilization of energetic stores in growth, whereas larvae fed with I. galbana and mixed diet utilized their reserves to increase their growth and development.

The dietary fatty acids profiles were comparables to previously described results (Albentosa et al. 1994). In agreement with Soudant et al. (1999), we observed that dietary fatty acids composition influences the fatty acid profile of the larvae $V$. pullastra, as highlighted the significant differences observed between diets in the content of different groups of fatty acids (Table 3). These results suggest a limited capacity for de novo synthesis of longchain PUFA in bivalves, as was previously reported (Delaunay et al. 1993; Caers et al. 2003).

PUFAs stored during larval development are used during metamorphosis to provide the energetic requirements for the synthesis of new structures (Delaunay et al. 1993). Beside other nutrients, lack of 22:6n-3 fatty acid in $T$. suecica diet might contribute to the higher mortality observed for larvae fed on the latter diet. Delaunay et al. (1993) reported that this fatty acid is partially replaced by $20: 5 n-3$ in polar lipids of larvae fed on Chaetoceros calcitrans with no apparent negative effects on growth. Nonetheless fewer pediveliger larvae were able to settle in comparison to those which accumulated primarily 22:6n-3 (Delaunay et al. 1993). Other deficient fatty acids in $T$. suecica diet, were long-chain n-6PUFA. Delaunay et al. (1993) showed that Pecten maximus larvae need also n-6PUFA as previously demonstrated for adult oysters (Trider \& Castell 1980). Although no significant relationships between the 20:4n-6 content and growth was observed, the important metabolic role of 20:4n-6 fatty acid as a precursor of prostaglandins (Smith \& Murphy 2003) may result in a high turnover and requirement for this fatty acid.

In summary, the higher content of 20:5n-3 in $T$. suecica diet compared to the other diets apparently was not enough to compensate the absence of 20:6n-3. In addition, the lower $\mathrm{n} 3: \mathrm{n} 6$ ratio pointed out deficiencies in the n-6 group, also important for larval growth. Those dietary deficiencies might prevent an adequate use of energetic reserves that were continuously accumulated in larvae and consequently preclude an adequate development and survival. Nonetheless when $T$. suecica is combined with I. galbana diet in mixture diet, nutritional deficiencies might be compensated as pointed out the survival rate. In addition, larvae fed on mixture diet reached postlarval stage with weight growth values higher than those fed on I. galbana, as was expected for multi-specific algal diets (Albentosa et al. 1993; Milke et al. 2004).

\section{Acknowledgements}

We thank B. González and L. Nieto in the biochemical analyses for their helpful technical assistance in the algal and larvae cultures. This work was funded by MEC. AGL2004$07023-\mathrm{C} 02-02 / \mathrm{ACU}_{\text {. }}$

\section{References}

Ackman, R.G. \& Hooper, S.N. (1973) Non-methylene-Interrupted fatty acids in lipids of shallow-water marine invertebrates. A comparison of two molluscs (Littorina littorea and Lunatia triserita) with the sand shrimp (Crangon septumspinosus). Comp. Biochem. Phys., 46B, 153-165.

Albentosa, M., Pérez-Camacho, A., Labarta, U., Beiras, R. \& Fernández-Reiríz, M.J. (1993) Nutritional value of algal diets to the clam spat Venerupis pullastra. Mar. Ecol. Prog. Ser., 97, 261269.

Albentosa, M., Labarta, U., Pérez-Camacho, A., Fernández-Reiríz, M.J. \& Beiras, R. (1994) Fatty acid composition of Venerupis pullastra spat fed on different microalgae diets. Comp. Biochem. Physiol., 108A, 639-648.

Albentosa, M., Labarta, U., Fernández-Reiríz, M.J. \& PérezCamacho, A. (1996) Fatty acid composition of Ruditapes decussatus spat fed on different microalgae diets. Comp. Biochem. Physiol., 113A, 113-119.

Alkanani, T., Parrish, C.C., Thompson, R.J. \& McKenzie, C.H. (2007) Role of fatty acids in cultured mussels, Mytilus edulis, grown in Notre Dame Bay, Newfoundland. J. Exp. Mar. Biol. Ecol., 348, 33-45.

Bayne, B.L. (1973) Aspects of the metabolism of Mytilus edulis during starvation. Netherlands J. Sea Res., 7, 399-341.

Beukema, J.J. \& De Bruin, W. (1979) Caloric vaues of the soft parts of the tellinid bivalve Macoma baltica (L.)as detemined by two methods. J. Exp. Mar. Biol. Ecol., 37, 19-30.

Caers, M., Coutteau, P., Lombeira, P. \& Sorgeloos, P. (1998) The effect of lipid suplementation on the growth and fatty acid composition of Tapes philippinarum. Aquaculture, 162, 287-299.

Caers, M., Couteau, P., Sorgellos, P. \& Gajardo, G. (2003) Impact of algal diets and emulsions on the fatty acid composition and content of selected tissues of adult broodstock of the Chilean scallop Argopecten purpuratus (Lamarck, 1819). Aquaculture, 217, 437452.

Christie, E.E. (1982) Lipid Analysis: Isolation, Separation, Identification and Structural Analysis of Lipids. Pergamon Press, Oxford, UK.

Chu, F.E. \& Greaves, J. (1991) Metabolism of palmitic, linoleic, and linolenic acids in adult oyster, Crassostrea virginica. Mar. Biol., 110, 229-236.

Delaunay, F., Marty, Y., Moal, J. \& Samain, J.F. (1993) The effect of monospecific algal diets on growth and fatty acid composition

(c) 2009 The Authors 
of Pecten maximus (L.) larvae. J. Exp. Mar. Biol. Ecol., 173, 163179.

Fernández-Reiríz, M.J., Pérez-Camacho, A., Ferreiro, M.J., Blanco, J., Planas, M., Campos, M.J. \& Labarta, U. (1989) Biomass production and variation in the biochemical profile (Total protein, carbohydrates, RNA, lipids and fatty acids) of seven species of marine microalgae. Aquaculture, 83, 17-37.

Fernández-Reiríz, M.J., Labarta, U., Albentosa, M. \& PérezCamacho, A. (1998) Effect of microalgal diets and commercial wheatgerm flours on the lipid profile of Ruditapes decussatus spat. Comp. Biochem. Physiol., 119A, 369-377.

Fernández-Reiríz, M.J., Labarta, U., Albentosa, M. \& PérezCamacho, A. (1999) Lipid profile and growth of the clam spat, Ruditapes decussatus (L.), fed with microalgal diets and cornstarch. Comp. Biochem. Physiol., 124B, 309-318.

Fernández-Reiríz, M.J., Labarta, U., Albentosa, M. \& PérezCamacho, A. (2006) Lipid composition of Ruditapes philippinarum spat: Effect of ration and diet quality. Comp. Biochem. Physiol. Part B, 144, 229-237.

Ferreiro, M.J., Perez-Camacho, A., Labarta, U., Beiras, R., Planas, M. \& Fernandez-Reiriz, M.J. (1990) Changes in the biochemical composition of Ostrea edulis larvae fed on different food regimes. Mar. Biol., 106, 395-401.

Helm, M.M. \& Laing, I. (1987) Preliminary observations on the nutritional value of Tahiti Isochrysis to bivalve larvae. Aquaculture, 62, 281-288.

Hendriks, I.E., Van Duren, L.A. \& Herman, P. (2003) Effect of dietary polyunsaturated fatty acids on reproductive output and larval growth of bivalves. J. Exp. Mar. Biol. Ecol., 296, 199-213.

Holland, D.L. (1978) Lipid reserves and energy metabolism in the larvae of benthic marine invertebrates. In: Biochemical and Biophysical Perspectives in Marine Biology, Vol. 4 (Malins, D.C. \& Sargent, J.R. eds), pp. 85-123. Academic Press, New York.

Irazu, C.E., Pollero, R.J. \& Brenner, R.R. (1984) Occurrence of a 22:2 non-methylene interrupted dienoic fatty acid and its seasonal distribution among lipids and tissues of the fresh water bivalve Diplodon delodontus from an isolated environment. Lipids, 19, 649-655.

Labarta, U., Fernández-Reiríz, M.J. \& Pérez-Camacho, A. (1999) Energy, biochemical substrates and growth in the larval development, metamorphosis and postlarvae of Ostrea edulis (L.). J. Exp. Mar. Biol. Ecol., 238, 227-244.

Leonardos, N. \& Lucas, I.A.N. (2000) The use of larval fatty acid as an index of growth in Mytilus edulis L. larvae. Aquaculture, 184, 155-166.

Marsh, J.B. \& Weinstein, D.B. (1966) Simple charring method for determination of lipids. J. Lipid Res., 7, 574-576.

Milke, L.M., Bricelj, V.M. \& Parrish, C.C. (2004) Growth of postlarval sea scallops, Placopecten magellanicus, on microalgal diets, with emphasis on the nutritional role of lipids and fatty acids. Aquaculture, 234, 293-317.

Pérez-Camacho, A., Román, G. \& Torre Cervigón, M. (1977) Experiencias en cultivos de larvas de tres especies de moluscos bivalvos: Venerupis pullastra (Montagu), Venerupis decussata (Linnaeus) y Ostrea edulis (Linnaeus). Bol. Inst. Esp. Ocean., III, 235, 7-62.

Pérez-Camacho, A., Albentosa, M., Fernández-Reiríz, M.J. \& Labarta, U. (1998) Effect of microalgal and inert diets on the growth performance and biochemical composition of Ruditapes decussatus seed: cornmeal and cornstarch. Aquaculture, 160, 89-102.

Pernet, F., Bricelj, V.M. \& Cartier, S. (2006) Lipid class dynamics during ontogeny of sea scallops, Placopecten magellanicus, in relation to metamorphic success and response to antibiotics. J. Exp. Mar. Biol. Ecol., 329, 265-280.
Pernet, F., Trembaly, R., Comeau, L. \& Guderley, H. (2007) Temperature adaptation in two bivalve species from different thermal habitats: energetics and remodelling of membrane lipids. J. Exp. Biol., 210, 2999-3014.

Romberger, H.P. \& Epifanio, C.E. (1981) Comparative effects of diets consisting of one or two algal species upon assimilation efficiencies and growth of juvenile oysters, Crassostrea virginica (Gmelin). Aquaculture, 25, 77-87.

Sewell, M.A. (2005) Utilization of lipids during early development of the sea urchin Evechinus cloroticus. Mar. Ecol. Prog. Ser., 304, $133-142$.

Smith, W.L. \& Murphy, R.C. (2003) The eicosanoids: cyclooxygenase, lipoxygenase and epoxygenase pathways. In: Biochemistry of lipids, lipoproteins and membranes. Vol. 36 (Vance, D.E. \& Vance, J.E. eds.), pp. 341-371. Elsevier Science, Amsterdam.

Snedecor, G.W. \& Cochran, W.G. (1980) Statistical Methods. Iowa State University Press, Ames, Iowa.

Soudant, P., Van Ryckeghem, K., Marty, Y., Moal, J., Samain, J.F. \& Sorgeloos, P. (1999) Comparison of the lipid class and fatty acid composition between a reproductive cycle in nature and standard hatchery conditioning of the pacific oyster Crassotrea gigas. Comp. Bioch. Physiol., 123B, 209-222.

Trider, D.J. \& Castell, J.D. (1980) Effect of dietary lipids on growth, tissue composition and metabolism of the oyster (Crassostrea virginica). J. Nutr., 110, 1303-1309.

Utting, S.D. (1986) A preliminary study on growth of Crassostrea gigas larvae and spat in relation to dietary protein. Aquaculture, 56, $123-136$.

Veniot, A., Bricelj, V.M. \& Beninger, P.G. (2003) Ontogenetic changes in gill morphology and potential significance for food acquisition in the scallop Placopecten magellanicus. Mar. Biol., 142, 123-131.

Waldock, M.J. \& Holland, D.L. (1984) Fatty acid metabolism in young oyster, Crassostrea gigas: polyunsaturated fatty acids. Lipids, 19, 332-336.

Watanabe, T. \& Ackman, R.G. (1974) Lipids and fatty acids of the American (Crassostrea virginica) and European flat (Ostrea edulis) oysters from a common habitat, and after one feeding with $D i$ crateria inornata or Isochrysis galbana. J. Fish. Res. Board Can., 31, 403-409.

Webb, K.L. \& Chu, F.E. (1983) Phytoplankton as food source for bivalve larvae. In: Proceedings of the 2nd International Conference on Aquaculture Nutrition: Biochemical and Physiological Approaches to Shellfish Nutrition (Pruder, G.D., Langdon, C. \& Conklind, D. eds), pp. 272-291. World Mariculture Society, Washington, D.C. Special Publication number 2.

Whyte, J.N.C., Bourne, N. \& Hodgson, C.A. (1989) Influence of algal diets on biochemical composition and energy reserves in Patinopecten yessoensis (Jay) larvae. Aquaculture, 78, 333-347.

Whyte, J.N.C., Bourne, N. \& Ginther, N.G. (1990) Biochemical and energy changes during embryogenesis in the rock scallop Crassadoma gigantea. Mar. Biol., 106, 239-244.

Zar, J.H. (1984) Biostatistical Analysis. Prentice-Hall, Englewood Cliffs, New Jersey.

Zhukova, N.V. (1991) The pathway of the byosynthesis of NonMethylene. Interrupted dienoic fatty acid Zhukova Zhukovas in mollusks. Comp. Biochem. Phys., 100, 801-804.

\section{Appendix 1}

Equations to describe the evolution of dry weight (DW), organic weight $(\mathrm{OW})$ and lipid content, expressed in their 
energy equivalents $\left(\mathrm{kJ} \mathrm{g}^{-1}\right)$ during larval development for the three experimental diets.

\section{T. suecica}

DW $\left(\mathrm{kJ} \mathrm{g}^{-1}\right)=4.5523 \mathrm{e}^{0.024 \text { time }}\left(r^{2}=0.91, P<0.001\right)$

OW $\left(\mathrm{kJ} \mathrm{g}^{-1}\right)=15.168 \mathrm{e}^{0.018 \text { time }}\left(r^{2}=0.63, P<0.001\right)$

Lipids $\quad\left(\mathrm{kJ} \quad \mathrm{g}^{-1}\right)=0.1305$ time $+1.2443 \quad\left(r^{2}=0.76\right.$,

$$
P<0.01)
$$

\section{I. galbana}

DW $\left(\mathrm{kJ} \mathrm{g}^{-1}\right)=-0.0089$ time $^{2}+0.2659$ time +4.3537

$$
\left(r^{2}=0.91, P<0.001\right)
$$

OW $\quad\left(\mathrm{kJ} \mathrm{g}^{-1}\right)=-0.0107 \mathrm{time}^{2}+0.2027$ time +16.501

$$
\left(r^{2}=0.74, P<0.001\right)
$$

Lipids $\quad\left(\mathrm{kJ} \mathrm{g}^{-1}\right)=-0.005$ time $^{2}+0.1492$ time +1.5688

$$
\left(r^{2}=0.77, P<0.001\right)
$$

Mixture

DW $\quad\left(\mathrm{kJ} \mathrm{g}^{-1}\right)=-0.0072$ time $^{2}+0.2183$ time +4.4689

$$
\left(r^{2}=0.91, P<0.001\right)
$$

OW $\quad\left(\mathrm{kJ} \mathrm{g}^{-1}\right)=-0.0034$ time $^{2}+0.0614$ time +16.626

$$
\left(r^{2}=0.52, P<0.001\right)
$$

Lipids $\quad\left(\mathrm{kJ} \mathrm{g}^{-1}\right)=-0.043$ time $^{2}+0.1336$ time +1.5857

$$
\left(r^{2}=0.94, P<0.001\right)
$$




\section{Author Query Form}

\section{Journal: $\quad$ ANU}

\section{Article: $\quad 701$}

Dear Author,

During the copy-editing of your paper, the following queries arose. Please respond to these by marking up your proofs with the necessary changes/additions. Please write your answers on the query sheet if there is insufficient space on the page proofs. Please write clearly and follow the conventions shown on the attached corrections sheet. If returning the proof by fax do not write too close to the paper's edge. Please remember that illegible mark-ups may delay publication.

Many thanks for your assistance.

\begin{tabular}{|l|l|l|}
\hline Query reference & Query & Remarks \\
\hline $\mathbf{1}$ & $\begin{array}{l}\text { AUTHOR: Please provide \% values in } \mathbf{g ~ k g}^{-1} \text { throughout the } \\
\text { text wherever applicable }\end{array}$ & \\
\hline $\mathbf{2}$ & AUTHOR: Please provide city name for Perkin-Elmer Inc. & \\
\hline 3 & $\begin{array}{l}\text { AUTHOR: Please provide city name for Agilent Technologies } \\
\text { Inc. }\end{array}$ & \\
\hline
\end{tabular}

\section{Answer to Queries:}

1 It is a survival percentage. It is not possible to transform in $\mathrm{g} \mathrm{kg}^{-1}$

2 Waltham

3 Santa Clara

\section{Changes to introduce:}

1- In page 4 line 3 change "(Table 1; ANOVA $P<0.05)$ " into "(Table 1)"

2- In page 4 line 36 change "(KJ g ${ }^{-1}$, dry weight, basis, Fig. 2)" into "(KJ g ${ }^{-1}$, Fig. 2)

3- In page 4 second column line 3, 4 and 6 change "DW-1" into "DW-1"

4- In Figure 2 legend (page 5) change "weight (c) (expressed in energy" into "weight (c) expressed in energy"

5- In page 5 line 39 and 41 change "DW-1" into "DW-1"

6- In Table 3 foot note (page 8) change "NMID, non-methhylene interrupted dienoic fatty aci" into "NMID, non-methylene interrupted dienoic fatty acid"

7- In Table 4 legend change "Isochrysis (B), Tetraselmis (C)" into "I. galbana (B), T. suecica (C)"

8- In table 4 change "Ns" in captital letters into "ns"

9- In page 9 line 43 change "20:6n-3" into "22:6n-3"

10- In the Acknowledgements section, change "This work was funded by MEC. AGL2004-07023-C02-02/ACU" into "This work was funded by CIRCLE (Climate Impact Research Coordination for a larger Europe) 08MDS0184402PR. 


\section{Please correct and return this set}

Please use the proof correction marks shown below for all alterations and corrections. If you wish to return your proof by fax you should ensure that all amendments are written clearly in dark ink and are made well within the page margins.

\begin{tabular}{|c|c|c|}
\hline Instruction to printer & Textual mark & Marginal mark \\
\hline Leave unchanged & ... under matter to remain & ( ) \\
\hline $\begin{array}{l}\text { Insert in text the matter } \\
\text { indicated in the margin }\end{array}$ & $h$ & $\begin{array}{l}\text { New matter followed by } \\
h \text { or } h \otimes\end{array}$ \\
\hline Delete & $\begin{array}{l}\text { I through single character, rule or underline } \\
\text { or }\end{array}$ & $\sigma$ or $\sigma(x)$ \\
\hline $\begin{array}{l}\text { Substitute character or } \\
\text { substitute part of one or } \\
\text { more word(s) }\end{array}$ & I through letter or & $\begin{array}{l}\text { new character / or } \\
\text { new characters / }\end{array}$ \\
\hline Change to italics & — under matter to be changed & $\leftarrow$ \\
\hline Change to capitals & $\equiv$ under matter to be changed & $\equiv$ \\
\hline Change to small capitals & $=$ under matter to be changed & $=$ \\
\hline Change to bold type & $\sim$ under matter to be changed & $\sim$ \\
\hline Change to bold italic & $\bar{\sim}$ under matter to be changed & $\underline{s i n}$ \\
\hline Change to lower case & Encircle matter to be changed & $\Rightarrow$ \\
\hline Change italic to upright type & (As above) & \\
\hline Change bold to non-bold type & (As above) & \\
\hline Insert 'superior' character & $\begin{array}{l}/ \text { through character or } \\
K \text { where required }\end{array}$ & $\begin{array}{l}y^{\prime} \text { or } y \\
\text { under character } \\
\text { e.g. } y^{2} \text { or } y^{2}\end{array}$ \\
\hline Insert 'inferior' character & (As above) & $\begin{array}{l}\lambda \\
\text { over character } \\
\text { e.g. } \hat{\Sigma}\end{array}$ \\
\hline Insert full stop & (As above) & $\odot$ \\
\hline Insert comma & (As above) & , \\
\hline Insert single quotation marks & (As above) & $\begin{array}{l}\dot{y} \text { or } \dot{x} \text { and/or } \\
\dot{y} \text { or } \dot{y}\end{array}$ \\
\hline Insert double quotation marks & (As above) & $\begin{array}{l}\ddot{y} \text { or } \ddot{y} \text { and/or } \\
\ddot{y} \text { or } \ddot{y}\end{array}$ \\
\hline Insert hyphen & (As above) & 1 \\
\hline Start new paragraph & 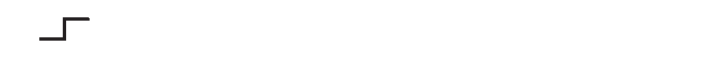 & 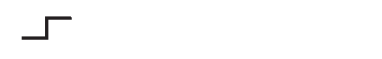 \\
\hline No new paragraph & $\infty$ & $\omega$ \\
\hline Transpose & $\sqcup$ & $\sqcup$ \\
\hline Close up & linking $\bigcirc$ characters & \\
\hline $\begin{array}{l}\text { Insert or substitute space } \\
\text { between characters or words }\end{array}$ & $\begin{array}{l}\text { I through character or } \\
\Lambda \text { where required }\end{array}$ & \\
\hline $\begin{array}{l}\text { Reduce space between } \\
\text { characters or words }\end{array}$ & $\begin{array}{l}\text { between characters or } \\
\text { words affected }\end{array}$ & $\uparrow$ \\
\hline
\end{tabular}

